\title{
Dynamic performance analysis of an integrated wind- photovoltaic microgrid with storage
}

\author{
Lawrence K. Letting $^{\mathrm{a}^{*}}$, Josiah L. Munda ${ }^{\mathrm{a}}$, Yskandar Hamam ${ }^{\mathrm{a}}$ \\ ${ }^{a}$ Tshwane University of Technology, Pretoria, South Africa
}

\begin{abstract}
This paper presents a power and energy management strategy for a wind-photovoltaic (PV) microgrid with an energy storage system (ESS) and PV array current injection on the DC-link. The ESS consists of a battery and a supercapacitor interfaced to the DC-link through bi-directional DC-DC converters. Cascade PI control is used to regulate the current supplied by the ESS to the DC-link. A fuzzy logic controller is proposed for efficient power sharing between the battery and the supercapacitor. A discrete-time simulation model is used to study the microgrid operation. The PV array model is implemented as an s-function. Using the proposed system, the power supplied to the grid is maintained at the desired reference value during changes in wind speed, solar radiation, and grid power demand. Results also show that the ESS improves the DC-link voltage stability during three-phase to ground faults.
\end{abstract}

Keywords: dfig, wind, photovoltaic, dc bus, storage

\section{Introduction}

Wind power plants require the presence of fast and flexible control of other generators in the power system so as to balance power generation with demand. The impacts of wind power integration that need to be considered include reactive power generation/voltage support, fault ride through capability, frequency control, and dispatch of conventional generating units [1]. A hybrid wind-PV microgrid with storage has a great potential to provide higher quality and more reliable power than a system based on a single resource [2].

In the recent past there has been an increased use of the Doubly Fed Induction Generator (DFIG)in wind energy conversion systems due to its special features. The unique capabilities of DFIG are: (1) it can supply power at constant voltage and frequency; (2) the rotor can operate in both sub-synchronous or super-synchronous speeds; (3) the rating of the power converter is approximately $30 \%$ of the rated wind turbine power; (4) the generated active and reactive power can be independently controlled; and (5) high efficiency and reduced mechanical stress on the wind turbine.

The operating performance of the DFIG depends on the stability of the DC bus voltage, especially during faults [3]. Large voltage fluctuations also lead to increased power losses in the power converters and injection of harmonics into the grid. Crowbar based solutions are the most commonly used for protection of power converters $[4,5]$. The crowbar protection is also enhanced by a DC chopper circuit with a resistor across the DC bus [6]. The resistor is used with the crowbar to stabilize the DC-bus voltage by dissipating excess power. The shortcomings of the crowbar circuits are: loss of DFIG active and reactive power controllability and magnetization is carried out by the stator [4], and the need for extra hardware in the DFIG which increase cost and reliability [7].

This study investigates the performance of the DFIG and the stability of the DC bus voltage when a

\footnotetext{
* Manuscript received August 4, 2013; revised November 4, 2013.

Corresponding author. Tel.: +27 12382 4824; E-mail address: LettingLK@gmail.com.
} 
PV array and an energy storage system are integrated on the DC bus. An initial study in [8] proposes integration of two sets of rechargeable batteries on the DFIG back-to-back converter DC-bus in a wind power generation scheme. One battery set is used to supply rotor currents while the other is used to smooth out wind turbine power output. Integration of PV array and battery storage on the DFIG DC-bus is presented in [9]. The battery in [9] is directly connected to DC-bus and is used to control the DC-bus voltage.

In this work, the energy storage system consists of a battery and a supercapacitor. Integration of battery and supercapacitor storage units offers a complementary scheme due to their different power and energy densities. A battery has a high energy density but requires accurate regulation of charge/discharge current within manufacturer specified range in order to increase its lifetime. A supercapacitor has high power density and longer lifetime but has the disadvantage of being more costly and having low energy density.

\section{System Configuration}

The microgrid is implemented as shown in Fig. 1. The battery and the supercapacitor are connected to the DC-bus through a bi-directional DC-DC converter based on the buck-boost topology. The PV array is connected to the DC-bus through a boost converter. The PV array, battery, and the supercapacitor models are implemented and interfaced to the 1.5MW DFIG wind power system in MATLAB SimPowerSystems [10]. A similar wind power generation scheme has been used to study integration of supercapacitor storage [11] and a direct current vector control method [12].

\subsection{Photovoltaic array}

The equivalent circuit of a solar cell is based on the well-known single-diode representation as shown in Fig. 2 [13]. The model contains a current source, G, diode, D , shunt resistance $R_{s h}$, and series resistance $R_{s}$. The diode current, ID, and the current through the shunt resistance $I_{s h}$ are evaluated using [13]:

$$
\begin{aligned}
& I_{D}=I_{o}\left\{\exp \left[\frac{q}{m k T_{c}}\left(V+I R_{s}\right)\right]-1\right\} \\
& I_{s h}=\frac{V+I R_{s}}{R_{s h}}
\end{aligned}
$$

where, $m$ is the idealizing factor, $k$ is Boltzmann's gas constant, $T_{c}$ is the cell absolute temperature, $q$ is the electronic charge, $V$ is the voltage imposed across the cell, and $I_{o}$ is the cell reverse saturation current. The current supplied to the load, $I$, is given by:

$I=I_{G}-I_{o}\left\{\exp \left[\frac{q}{m k T_{c}}\left(V+I R_{s}\right)\right]-1\right\}-\frac{V+I R_{s}}{R_{s h}}$

where $I_{G}$ is the light-generated current. Using the manufacturer supplied data for BP solar 230W PV module [14], the model shown in Fig. 3 was formulated as a current source and implemented as a Simulink s-function. The model inputs are the ambient solar radiation, $S$, ambient temperature, $T_{a}$, and module operating voltage, $V_{m}$. The outputs are the current $I_{m}$ and the maximum power $P_{\max }$. The developed model is used to implement the PV array. 


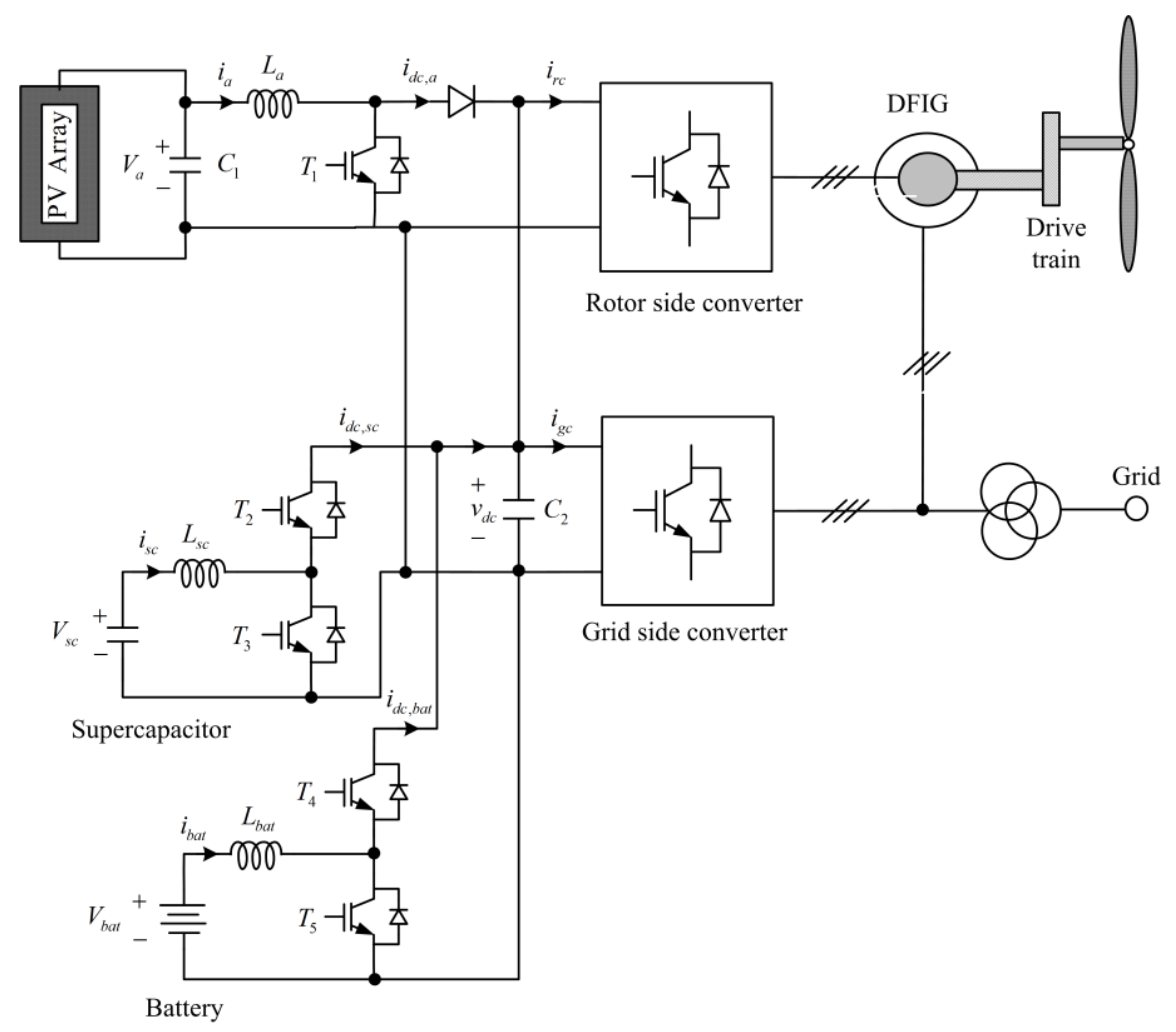

Fig. 1. Schematic diagram of wind-PV microgrid with battery and supercapacitor storage.

\subsection{Battery model}

The CIEMAT battery model [15] is used in this study. The model is able to predict charge and discharge characteristics of lead-acid batteries produced by different manufacturers eliminating the need for more costly and time consuming effort of developing parameters for each brand of battery. The battery dynamics are described by modelling the state of charge (SoC), voltage equation, and temperature effects. The instantaneous battery state of charge is given by:

$$
\operatorname{SoC}(t)=\operatorname{SoC}\left(t_{0}\right)-\frac{1}{C_{10}} \int_{t_{0}}^{t} I_{b a t} \cdot d t
$$

where $\operatorname{SoC}\left(t_{0}\right)$ is the initial state of charge, $C_{10}$ represents the battery capacity over a discharge regime at constant current, $I_{10}$, in a time span of 10 hours.

\subsection{Supercapacitor model}

A simplified model that consists of an ideal capacitor and an equivalent series resistance (ESR) as shown in Fig. 4 is used. The ESR is static and is used to account for resistive losses in the dielectric, plate material, and electrolytic solution [16]. The actual capacitance and ESR values vary with the terminal voltage, charging rate, current, and temperature. 


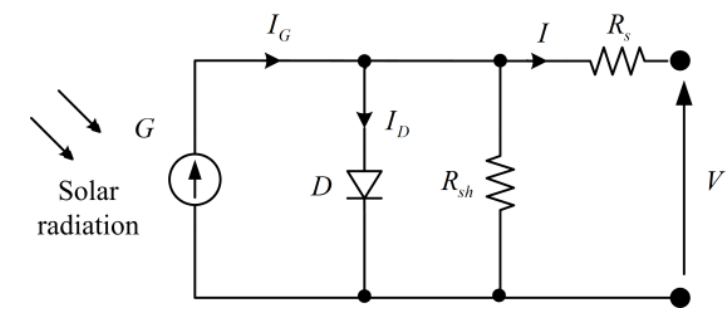

Fig. 2. Equivalent circuit of a solar cell.

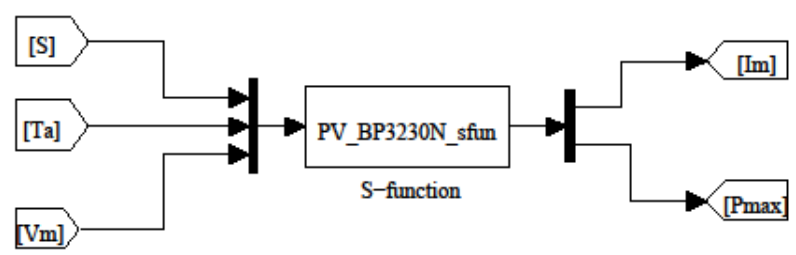

Fig. 3. PV module Simulink model.

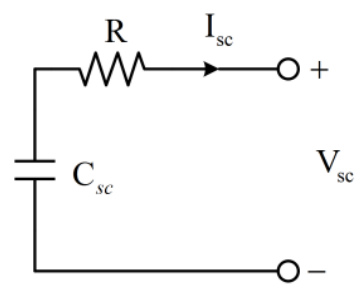

Fig. 4. ESR model of a supercapacitor.

\section{Power Management}

The power management scheme of the microgrid is implemented as shown in Fig. 5. The control scheme is based on the power balance equation expressed as:

$$
P_{s t o, r e f}=P_{d}-P_{g e n}-P_{p v}+P_{L, \text { filter }}+P_{d c, \text { ref }}
$$

where $P_{\text {sto, ref }}$ is the extra power that needs to be generated or stored, $P_{d}$ is the requested power demand, $P_{g e n}$ is the total power generated by DFIG stator and rotor, $P_{p v}$ is the power generated by PV array, $P_{L, \text { filter }}$ is the grid filter power loss, and $P_{d c \text {,ref }}$ is the power needed to charge the DC-bus capacitor. The grid filter power loss is evaluated using:

$$
P_{L, \text { filter }}=R_{f}\left(i_{d}^{2}+i_{q}^{2}\right)
$$

where $R_{f}$ is the grid filter resistance, and $i_{d}$ and $i_{q}$ are the grid current components in $d q$-reference frame. The fuzzy logic controller in the energy storage system (ESS) shown in Fig. 6 sets the power sharing ratio, $K_{\text {bat }}$ such that:

$$
\begin{aligned}
& P_{b a t}=K_{b a t} P_{s t o, r e f} \\
& P_{s c}=\left(1-K_{b a t}\right) P_{s t o, r e f}
\end{aligned}
$$




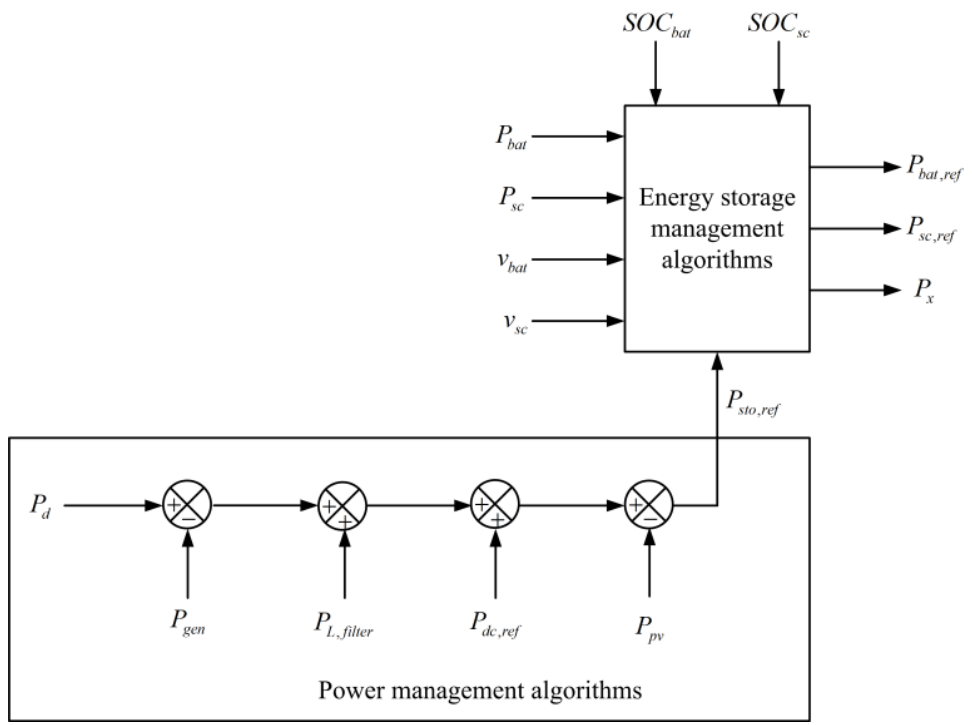

Fig. 5. Power and energy storage management algorithms.

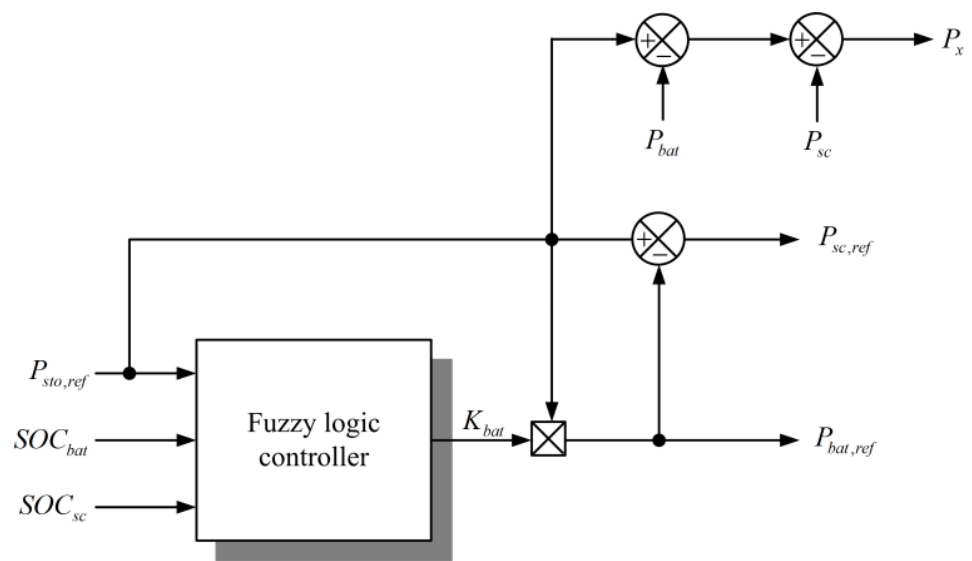

Fig. 6. Energy storage management algorithms.
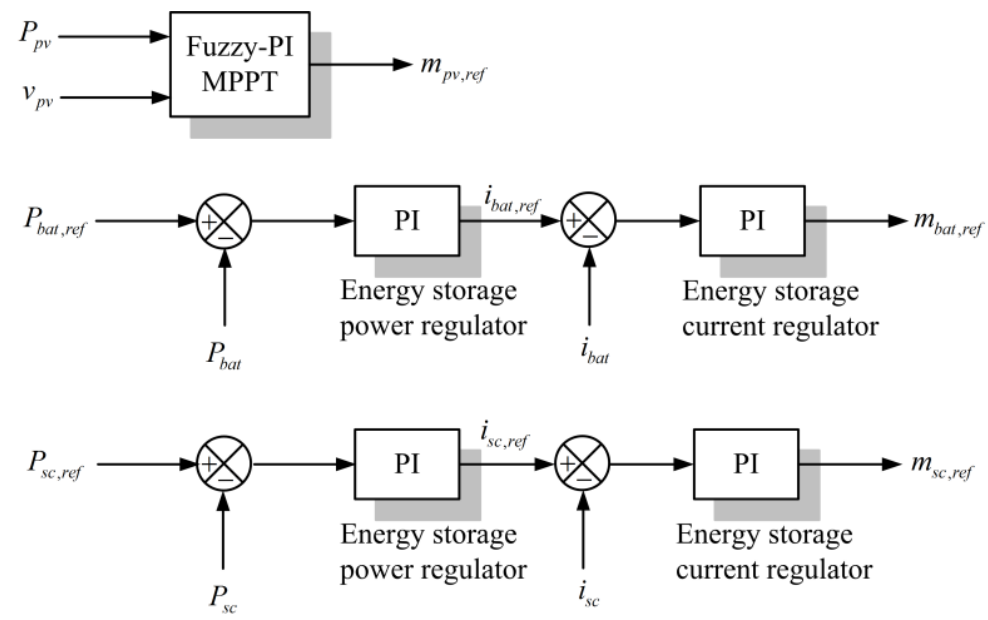

Fig. 7. PV array, battery, and supercapacitor converter duty cycle reference. 


$$
0 \leq K_{b a t} \leq 1
$$

where $P_{b a t, r e f}$ is the battery power reference and $P_{s c \text {,ref }}$ is the supercapacitor power reference. The power references are used to determine the desired current reference for the storage units.

The cascade PI control scheme shown in Fig. 7 is used to regulate the current supplied to the DC-bus by the ESS. The current-reference, $i_{d c, \text { ref }}$, required to charge the DC-bus is evaluated using a voltage feedback PI control using:

$$
i_{d c, r e f}=\left(k_{v p}+\frac{k_{v i}}{s}\right)\left(v_{d c, r e f}-v_{d c}\right)
$$

where $k_{v p}$ and $k_{v i}$ are the PI controller gains, and $v_{d c, r e f}$ is the DC-bus voltage reference. The power reference required for charging the DC-bus is then obtained using:

$$
P_{d c, r e f}=v_{d c} i_{d c, r e f}
$$

The converter duty cycles for the PV array, $m_{p v, \text { ref }}$, battery storage, $m_{b a t, r e f}$, and supercapacitor storage, $m_{s c, r e f}$ are determined as shown in Fig. 7. The controllers are optimized on-line using the s-function based particle swarm optimization algorithm [17]. The load, $P_{x}$, that remain unmet at different time intervals is recorded and can be used to determine proper system sizing or for load dispatch in the microgrid.

A Mamdani type fuzzy logic controller is used for power sharing in the ESS. The inputs of the FLC are the desired power from the energy storage, $P_{\text {sto, ref }}$, battery state of charge, $S o C_{b a t}$, and supercapacitor state of charge, $S o C_{s c}$. The controller output, $K_{b a t}$, is the battery power sharing ratio. The membership functions are shown in Fig. 8 and the rule base is implemented as shown in Table 1. The linguistic variables for $P_{\text {sto,ref }}$ are: NE, ZE, and PO, and they represent "negative"," "zero", and "positive" respectively. The linguistic variables for $S o C_{b a t}$, and $S o C_{s c}$ are: LO, ME, and HI, and they represent "low", "medium", and "high" respectively. $K_{b a t}$ is represented by linguistic variables: SM, ME, and LG, which represent "small", "medium", and "large" respectively.
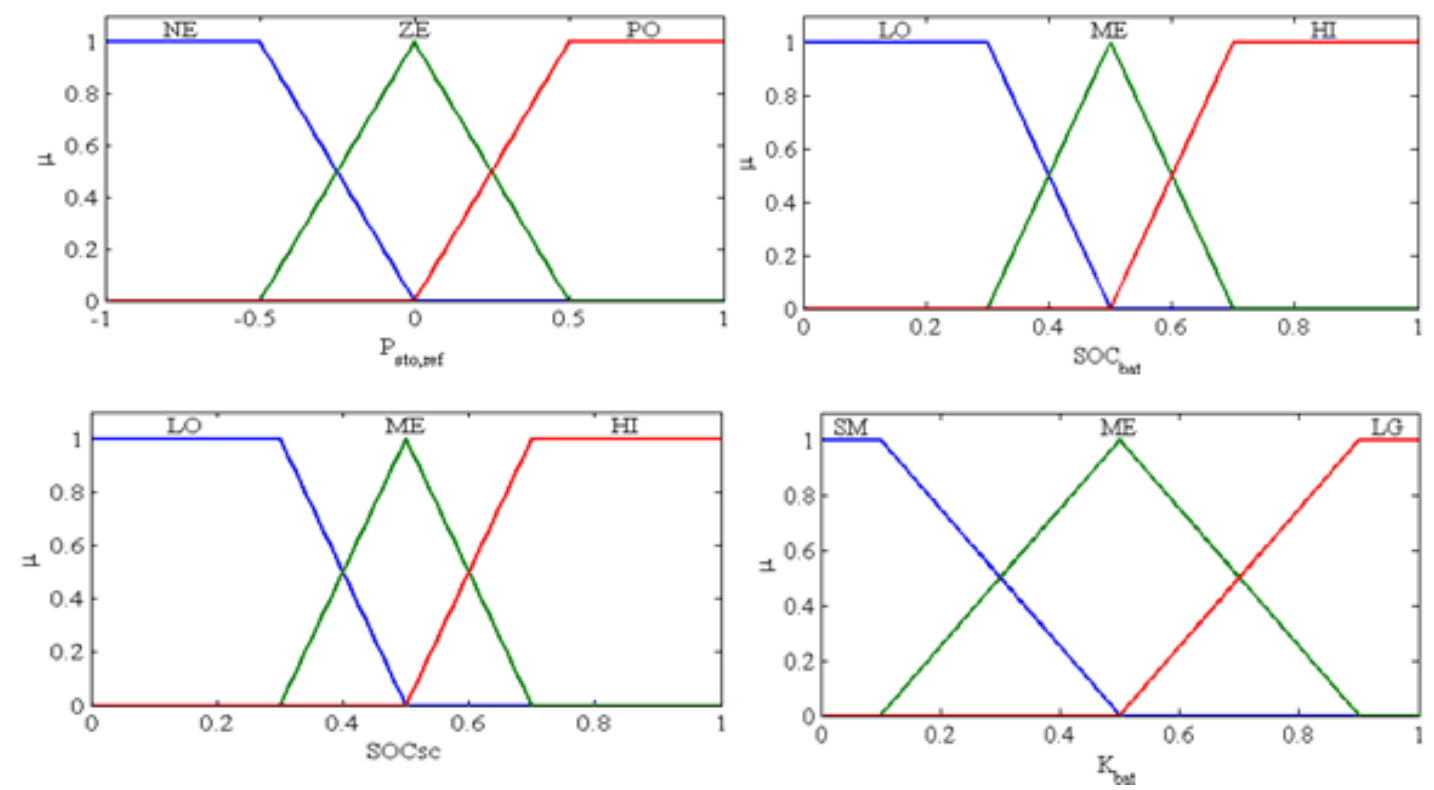

Fig. 8. Energy storage fuzzy logic controller input membership functions. 
Table 1. Energy storage fuzzy logic controller rule base

\begin{tabular}{|c|c|c|c|}
\hline \multirow{2}{*}{$\boldsymbol{P}_{\text {sto,ref }}$} & \multicolumn{3}{|c|}{$S O C_{b a t}\left(S o C_{s c}=L O\right)$} \\
\hline & LO & ME & $\mathrm{HI}$ \\
\hline LO & ME & $\mathrm{ME}$ & SM \\
\hline ME & ME & LG & LG \\
\hline $\mathrm{HI}$ & $\mathrm{ME}$ & ME & LG \\
\hline \multirow{2}{*}{$\boldsymbol{P}_{\text {sto,ref }}$} & \multicolumn{3}{|c|}{$S O C_{b a t}\left(S o C_{s c}=M E\right)$} \\
\hline & LO & ME & $\mathrm{HI}$ \\
\hline $\mathrm{NE}$ & LG & ME & SM \\
\hline $\mathrm{ZE}$ & SM & ME & ME \\
\hline $\mathrm{PO}$ & SM & $\mathrm{ME}$ & LG \\
\hline \multirow{2}{*}{$\boldsymbol{P}_{\text {sto,ref }}$} & \multicolumn{3}{|c|}{$S O C_{b a t}\left(S o C_{s c}=H I\right)$} \\
\hline & LO & $\mathrm{ME}$ & $\mathrm{HI}$ \\
\hline $\mathrm{NE}$ & LG & ME & SM \\
\hline $\mathrm{ZE}$ & SM & $\mathrm{ME}$ & $\mathrm{ME}$ \\
\hline $\mathrm{PO}$ & SM & $\mathrm{ME}$ & LG \\
\hline
\end{tabular}

Table 2. Microgrid system sizing

\begin{tabular}{lc}
\hline DFIG and wind turbine & $1.5 \mathrm{MW}$ \\
PV array & $0.7 \mathrm{MW}$ \\
Supercapacitor & $123.5 \mathrm{~F}$ \\
Supercapacitor ESR & $5.7 \times 10^{-3} \Omega$ \\
Battery & $750 \mathrm{~V}, 3000 \mathrm{Ah}$ \\
\hline
\end{tabular}

\section{Simulation Results and Discussion}

Simulations are performed to verify the performance of the microgrid with the proposed power and energy management strategies. The first study investigates performance under normal operation with step changes in wind, solar radiation, and grid power demand. The next studies investigate performance during three-phase short circuit faults. Simulations are carried out in MATLAB/Simulink using a discrete fixed step solver and a time step of $10 \mu \mathrm{s}$. The simulation model is implemented as shown in Fig. 9. The system sizing is shown in Table 2 .

\subsection{Response under normal operation}

The system is studied during normal operation with an initial wind speed of $10 \mathrm{~m} / \mathrm{s}$, solar radiation of $0.5 \mathrm{~kW} / \mathrm{m}^{2}$, ambient temperature of $25^{\circ} \mathrm{C}$, and a grid power demand of $1.0 \mathrm{p}$.u. The initial battery and supercapacitor state of charge are $70 \%$ and $50 \%$ respectively. Simulations are carried out with the following step changes: at $\mathrm{t}=1 \mathrm{~s}$ solar radiation step change from 0.5 to $1.0 \mathrm{~kW} / \mathrm{m}^{2}$ at $\mathrm{t}=1.5 \mathrm{~s}$ grid power demand step change from 1.0 to 0.7 p.u., and at $\mathrm{t}=2 \mathrm{~s}$ simultaneous wind speed, grid power demand, and solar radiation step changes from $10 \mathrm{~m} / \mathrm{s}$ to $15 \mathrm{~m} / \mathrm{s}, 0.7$ to 1.0 p.u., and 1.0 to $0.8 \mathrm{~kW} / \mathrm{m}^{2}$ respectively. The system response is shown in Figs. 10-12.

It is observed in Fig. 10 that during start-up the system reaches steady state at $\mathrm{t}=0.3 \mathrm{~s}$ and is able to supply the required power to the grid. The slow variations in power generated by the DFIG stator $\left(P_{s}\right)$ due to the large wind turbine time constant is compensated by power supplied to the grid via the grid side converter $P_{g c}$. Between $\mathrm{t}=0.3 \mathrm{~s}$ and $\mathrm{t}=1.5 \mathrm{~s}$, power is supplied to the grid from the energy storage. Fig. 11 
shows that the battery supplies more current than the supercapacitor because it has a higher state of charge. The storage units start charging at $t=1.5 \mathrm{~s}$ when the grid power demand reduces and there is surplus power. Fig. 11 shows that the charging current of the supercapacitor is higher than that of the battery due to its lower state of charge compared to the battery. Between $t=2.0 \mathrm{~s}$ and $\mathrm{t}=2.5 \mathrm{~s}$ the battery and supercapacitor charging currents continue rising as $P_{s}$ increases due to increase in wind speed. The battery power sharing ratio, DC-bus voltage, and the rotor speed responses is shown in Fig. 12.

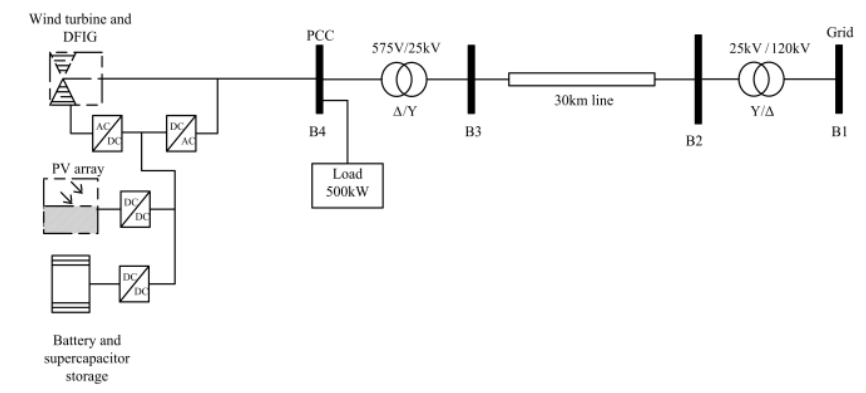

Fig. 9. System under study.

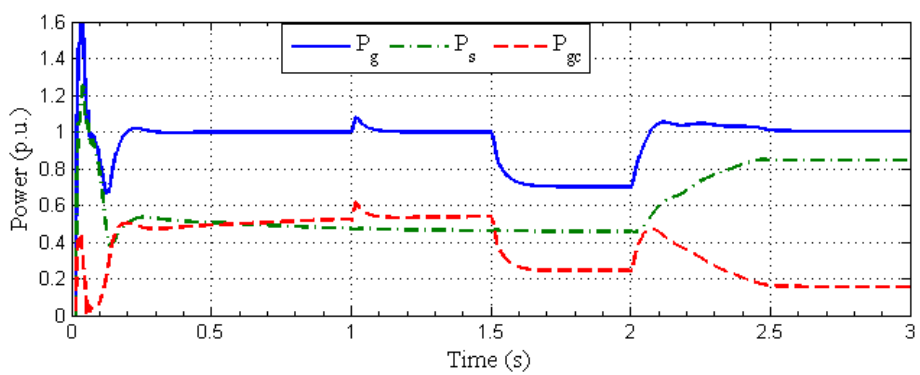

Fig. 10. Power generation during changes in solar radiation, wind speed, and power demand.

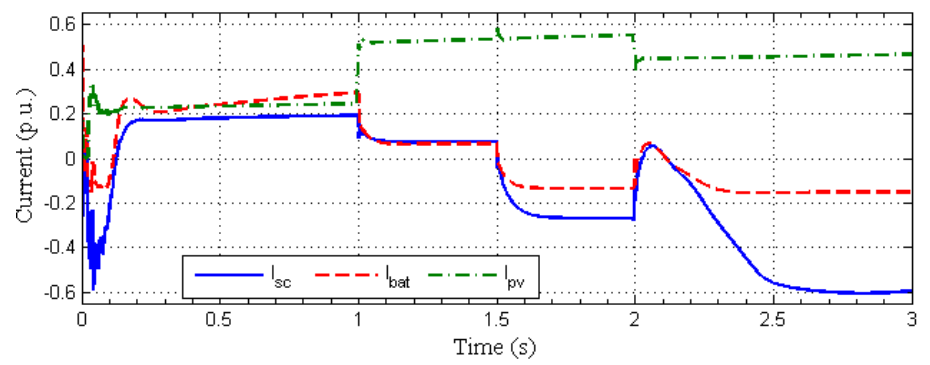

Fig. 11. Response of battery current $\left(\mathrm{I}_{\mathrm{bat}}\right)$, supercapacitor current $\left(\mathrm{I}_{s c}\right)$, and PV array current $\left(\mathrm{I}_{\mathrm{pv}}\right)$ during changes in solar radiation, wind speed, and power demand.

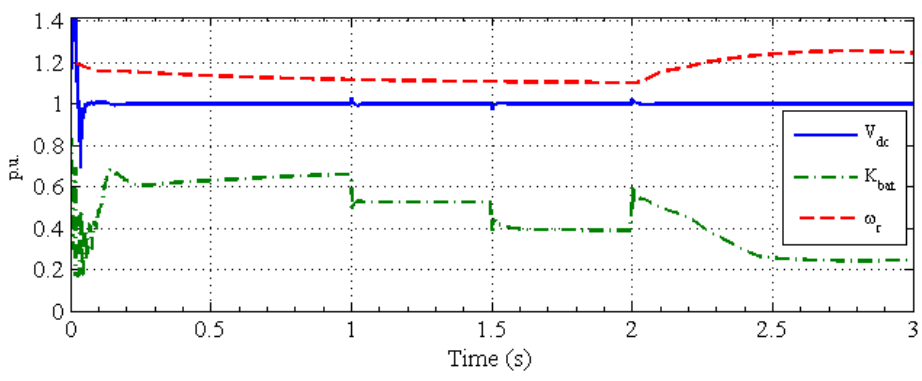

Fig. 12. Response of DC-bus voltage $\left(\mathrm{V}_{\mathrm{dc}}\right)$, battery power sharing ratio $\left(\mathrm{K}_{\text {bat }}\right)$, and rotor speed $\left(\omega_{r}\right)$ during changes in solar radiation, wind speed, and power demand. 


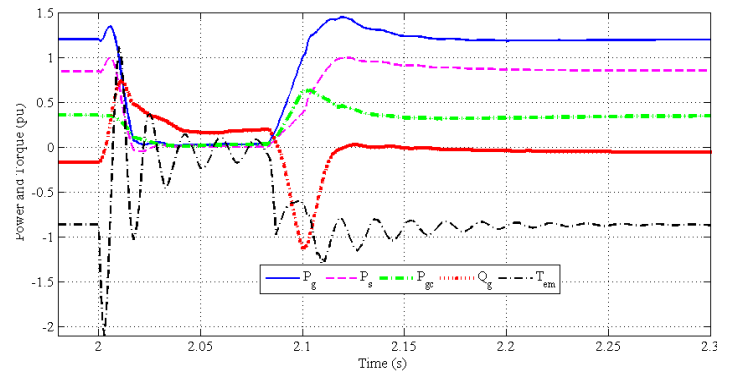

Fig.13. Active power at PCC $\left(\mathrm{P}_{\mathrm{g}}\right)$, DFIG stator $\left(\mathrm{P}_{\mathrm{s}}\right)$, grid side converter $\left(\mathrm{P}_{\mathrm{gc}}\right)$, reactive power at $\mathrm{PCC}\left(\mathrm{Q}_{\mathrm{g}}\right)$, and DFIG developed electromagnetic torque $\left(\mathrm{T}_{\mathrm{em}}\right)$ during three-phase to ground fault.

\subsection{Response during a three phase to ground fault}

A three-phase to ground fault is introduced at point B2 at $\mathrm{t}=2 \mathrm{~s}$ for 5 cycles when the system is running at steady state with a wind speed of $15 \mathrm{~m} / \mathrm{s}$, solar radiation of $1 \mathrm{~kW} / \mathrm{m}^{2}$, ambient temperature of $25{ }^{\circ} \mathrm{C}$, and grid power demand of 1.2 p.u. The system response is shown in Fig. 13-15.

Fig. 13 shows that both the power generated by the DFIG stator and the total power supplied to the grid falls to zero. The generated reactive power also increases to a peak value of 0.7 p.u before slowly decreasing. The generated reactive power during the fault is absorbed by the energy storage system and which helps in stabilizing the dc-bus voltage. The DFIG developed electromagnetic torque oscillates as it decreases to zero during the fault.

The variation of PV array, battery, supercapacitor, and rotor converter currents is shown in Fig. 14. It is observed that the PV array current reduces during the fault due to the increase in dc--bus voltage. The supercapacitor absorbs most of the fault currents while the battery current remains almost constant. The DC-bus voltage, battery power sharing ratio, and rotor speed variation is shown in Fig. 15. DC-bus voltage is maintained within p.u. of the reference value during the fault. The rotor speed also increases during the fault due to the decrease in developed electromagnetic torque.

When the fault clears, the DFIG consumes reactive power with a peak value of -1.2 p.u. There is a sudden decrease in dc-bus voltage to a minimum of 0.8 p.u. because it supplies the increased current demand from the rotor circuit. Fig. 14 shows that the average dc current $\left(\mathrm{I}_{\mathrm{dc}, \mathrm{rc}}\right)$ supplied to the rotor circuit rises to a peak value of 0.6 p.u. when the fault clears.

Fig. 16 shows comparison of DC-bus voltage response during three-phase fault for the same system with and without the energy storage system. Without the energy storage system, the fault currents charge the DC-bus capacitor leading to high voltage rise. An energy storage system therefore improves the system fault ride-through capability. The system without energy storage in Fig. 16 does not have PV array current injection on the DC-bus.

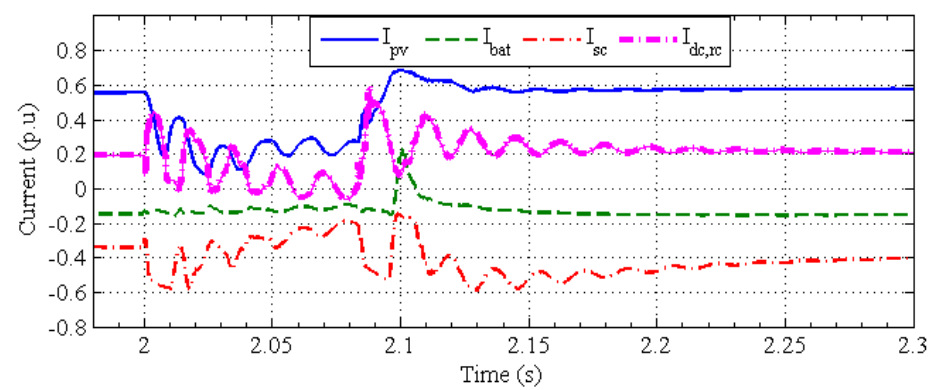

Fig. 14. PV array current $\left(\mathrm{I}_{\mathrm{pv}}\right)$, battery current $\left(\mathrm{I}_{\mathrm{bat}}\right)$, supercapacitor current $\left(\mathrm{I}_{\mathrm{sc}}\right)$, and current supplied by the rotor to the DC-bus $\left(\mathrm{I}_{\mathrm{dc} ; \mathrm{rc}}\right)$ during three-phase to ground fault.to ground fault. 


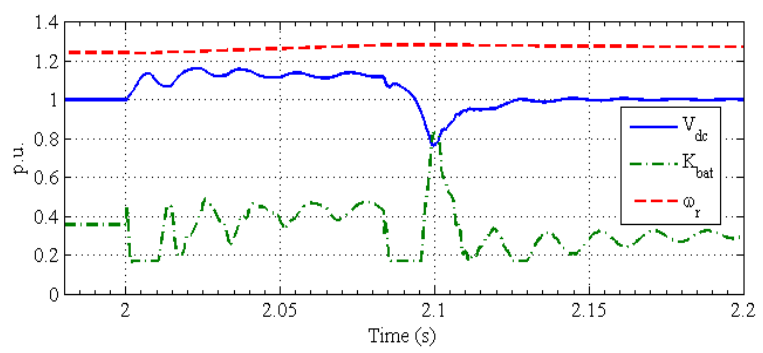

Fig. 15. DC-bus voltage $\left(\mathrm{V}_{\mathrm{dc}}\right)$, battery power sharing ratio $\left(\mathrm{K}_{\mathrm{bat}}\right)$, and rotor speed $\left(\omega_{r}\right)$ during three-phase to ground fault.

\section{Conclusion}

This paper has proposed a power and energy management strategy for a wind-PV microgrid with an energy storage system (ESS) and PV array current injection on the the DC-link. The ESS consists of a battery and a supercapacitor connected to the DC-link through a bi-directional DC-DC converter. Cascade PI control is used to regulate the current supplied by the ESS to the DC-link. A fuzzy logic controller is proposed for efficient power sharing between the battery and the supercapacitor. The DFIG grid side converter is used to supply power from the ESS and the PV array to the grid. The power supplied to the grid is maintained at the desired reference value by using the ESS either as a source or a sink of active power. Using the proposed scheme fluctuations in active power supplied to the grid due to variations in wind speed and solar radiation is minimized. Results also show that the ESS improves the DC-link voltage stability during three-phase to ground faults.

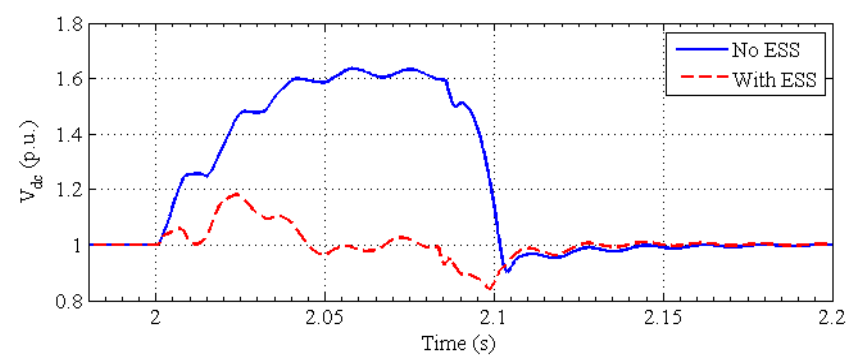

Fig. 16. Comparison of DC-bus voltage $\left(\mathrm{V}_{\mathrm{dc}}\right)$ response during 3-phase to ground fault: with and without energy storage system (ESS).

\section{References}

[1] Slootweg, J. G., Wind power modelling and impact on power system dynamics, Ph.D. thesis, Thechnische Universiteit Delft, Netherlands, 2003.

[2] Wang, C. and Nehrir, M., Power management of a standalone wind/photovoltaic/fuel cell energy system, IEEE Transactions on Energy Conversion, 2008, 23(3):957-967.

[3] Liu, C., Huang, X., Chen, M., and Xu, D., Flexible control of dc-link voltage for doubly fed induction generator during grid voltage swell, in Energy Conversion Congress and Exposition, (2010), pp. 3091-3095.

[4] Chen, Z., Guerrero, J., and Blaabjerg, F., A review of the state of the art of power electronics for wind turbines. IEEE Transactions on Power Electronics, 2009, 24(8):1859-1875.

[5] Meegahapola, L., Littler, T., and Flynn, D., Decoupled dfig fault ride-through strategy for enhanced stability performance during grid faults, IEEE Transactions on Sustainable Energy, 2010, 1(3):152-162.

[6] Yang, J., Fletcher, J., and O'Reilly, J., A series-dynamic resistor-based converter protection scheme for doubly-fed induction generator during various fault conditions, IEEE Transactions on Energy Conversion, 2010, 25(2):422-432.

[7] Yang, L., Xu, Z., Ostergaard, J., Dong, Z. Y., and Wong, K. P., Advanced control strategy of dfig wind turbines for power system fault ride through, IEEE Transactions on Power Systems, May 2012, 27(2):713 -722.

[8] Yang, T., Initial study of using rechargeable batteries in wind power generation with variable speed induction generators, Renewable Power Generation, IET, June 2008, 2(2):89 -101. 
[9] Ghoddami, H., Delghavi, M. B., and Yazdani, A., An integrated wind-photovoltaic-battery system with reduced powerelectronic interface and fast control for grid-tied and off-grid applications, Renewable Energy, 2012; 45:128 - 137.

[10] Mathworks, MATLAB SimPowerSystems TM, Documentation, September 2007, R2007b.

[11] Qu, L. and Qiao, W., Constant power control of dfig wind turbines with supercapacitor energy storage, IEEE Transactions on Industry Applications, Jan-Feb 2011;47(1):359-367.

[12] Li, S., Haskew, T., Williams, K., and Swatloski, R., Control of dfig wind turbine with direct-current vector control configuration, IEEE Transactions on Sustainable Energy, 2012;3(1):1-11.

[13] Masters, G. M., Renewable and Efficient Electric Power Systems, John Wiley \& Sons Inc., Hoboken, New Jersey 2004.

[14] BP Solar, 230 Watt Photovoltaic Module of Poly 3-Series BP 3230 N, Datasheet, BP Solar, October 2012.

[15] Gergaud, O., Robins, G., Multon, B., and Ahmed, H. B., Energy modeling of a lead-acid battery within hybrid wind / photovoltaic systems, in EPE Toulouse, France, 2003:1-10.

[16] Li, W. and Joos, G., A power electronic interface for a battery supercapacitor hybrid energy storage system for wind applications, in Power Electronics Specialists Conference, $2008: 1762-1768$.

[17] Letting, L., Munda, J., and Hamam, Y., Optimization of a fuzzy logic controller for pv grid inverter control using s-function based pso, Solar Energy, 2012;86(6):1689-1700. 